IRA-International Journal of Management \&

Social Sciences

ISSN 2455-2267; Vol.17, Issue 04 (Q.4 2021)

Pg. no. 99-105.

IRA Academico Research

\title{
Information Science: Fields and Technological Issues \& Challenges in Developing \& Developed Nations
}

\author{
P. K. Paul (i) ${ }^{1 \#}$, P. S. Aithal ${ }^{2}$, R. Saavedra ${ }^{3}$, K.S. Tiwary 4 , B. Aremu ${ }^{5}$, S. Mewada ${ }^{6}$ \\ ${ }^{1}$ Executive Director, MCIS, Department of CIS, Information Scientist (Offg.), Raiganj University, \\ India. \\ ${ }^{2}$ Vice Chancellor, Srinivas University, Karnataka, India. \\ ${ }^{3}$ Director \& Chair, International Inter-University Programs, Azteca University, México. \\ ${ }^{4}$ Dean (Science \& Management), Raiganj University, India. \\ 5 Vice Chancellor, Crown University, Intl. Chartered Inc. (CUICI) Argentina Campus, Argentina. \\ ${ }^{6}$ President, International Scientific Organization for the Science, Engineering and Technology, \\ India.
}

\# corresponding author

Type of Work: Peer Reviewed.

DOl: https://dx.doi.org/10.21013/jmss.v17.n4.p1

\section{How to cite this paper:}

Paul, P.K., Aithal, P.S., Saavedra, R., Tiwary, K.S., Aremu, B., Mewada, S. (2021). Information Science:

Fields and Technological Issues \& Challenges in Developing \& Developed Nations. IRA-International Journal of Management \& Social Sciences (ISSN 2455-2267), 17(4), 99-105. DOI:

https://dx.doi.org/10.21013/jmss.v17.n4.p1

(C) IRA Academico Research.

This full-text of this paper is available under Open Access subject to a Creative Commons Attribution-NonCommercial 4.0 International License $\boldsymbol{T}$ and further subject to a proper citation of its primary publication source.

Disclaimer: The scholarly papers as reviewed and published by IRA Academico Research are the views and opinions of their respective authors and are not the views or opinions of IRA Academico Research. IRA Academico Research disclaims any harm or loss caused due to the published content to any party.

IRA Academico Research is an institutional publisher member of Publishers International Linking Association Inc. (PILA-CrossRef), USA. Being an institutional signatory to the Budapest Open Access Initiative, Hungary, the content published by IRA Academico Research is available under Open Access. IRA Academico Research is also a registered content provider under Open Access Initiative Protocol for Metadata Harvesting (OAI-PMH).

This paper is peer-reviewed following IRA Academico Research's Peer Review Program $[$ ?

P.K. Paul (D)/0000-0003-1140-3369[] 


\section{ABSTRACT}

Information is the power and Technology is the driving force for the development of all the facets. Information Science and Technology as a field of study and professional practice is therefore responsible for providing information and technology solutions to different organizations, institutions, sectors, fields, and even to individuals. Information Science and Technology is an emerging field and interdisciplinary in nature that has already been gathered from previous sources and chapters. Information Science and Technology is very diverse and treated in different perspectives viz. information, technological solutions, domain-specific solutions, and so on. Regarding the technologies, it also holds wider coverage in tools, techniques, systems, and technologies. Though Information Science and Technology is available with different names there are certain reasons for the development of each nomenclature/ subject. This paper has discussed the issues and suggestions regarding Information Science in its educational and technological context.

Keywords: Information Science, IT, Computing, Development Studies, Issues and Challenges,

\section{Introduction}

Contemporary Scenario

Information Science is dedicated to information and technological solutions with different tools, techniques, subtechnologies and due to its importance, it has now reached its applications in wider areas and fields [1], [5], [15]. Initially only basic technologies viz. Networking Technologies, Web Technologies, Database Technologies, Multimedia Technologies, Communication Technologies, etc. have played a leading role in the information activities and gradually other emerging technologies have also been using viz. Cloud Computing, Big Data Technologies, Human-Computer Interaction, Usability Engineering, Internet of Things (IoT), Converged Networking, Green Computing, etc. Further, it is applicable in diverse fields and areas viz. Health Science, Biological Science, Sociology, Commerce and Business, Environment and Ecology, Education, and so on [3], [11],[24]. Further Information Science is started with different other nomenclature viz. Information Science and Technology, Information Science and Computing, Computer and Information Science, Informatics, Information Systems and Technology, and so on. Though all the areas are dedicated to Information activities there are few differences among these. Moreover, there are certain issues, and challenges in regard to Information Science [7], [12], [23].

\section{Objectives}

The present paper entitled 'Information Science: Fields and Technological Issues \& Challenges in Developing \& Developed Nations' is with the following aim and agenda viz.-

- To learn about the basics of Information Science issues and challenges in respect of broadness, technomanual management, interdisciplinary management, misconception management, etc.

- To know about the growing nomenclature and their issues and challenges in brief.

- To know about the technology issues in Information Science with reference to Cloud Computing, Big Data, and other allied technologies.

- To learn about the educational and manpower development related issues and allied areas in brief.

\section{Information Science: Core Issues and Challenges}

The studies show that Information Science and Technology is a broader field of academics and practiced in the information centers and foundations, information systems and development, IT Industries and sector, various fields for the information and technological solutions viz. [2], [8], [22]—

- Education, Teaching and Learning

- Medicine and Health Systems, Sector and Science

- Government, administration and politics

- Environment, Ecology, and Earth Sciences 
- Business and Commerce

- Industries and Management

- Information Center and Foundations

- Chemical and Similar Components / Sectors

- Social Science, Systems and Development

The above are tentative and there are many other areas where Information Science and Technology is perfectly applicable and emerging [6], [21], [23]. The solutions of Information Science and Technology are basically rendered by the IT components and also Traditional Information Systems such as Documentation, Indexing, Abstracting, and other knowledge management systems. The technologies are changing rapidly and it is also reflected in the overall information systems and infrastructure. Cloud Computing is changing the enter information systems, infrastructure radically and it is growing with huge uses. Further as far as Big Data and allied technologies are concerned the reason for adopting the same are included in managing a large amount of data. And in this regard, the aspect of cyber-security and the Internet of Things (IoT) must be noted. In regard to educational programs on Information Science and Technology, many universities are adopting a different approach, focus, and concentration around the world whereas skill-based and emerging technologies are also noted. As far as domain-centric Information Science and Technology the boom is also remarkable. Regarding Cloud Computing, Big Data and Allied Technologies the manpower development issues have been noted with introducing programs and degrees in many countries [4], [10], [18].

\section{Suggestion with Concluding Remarks}

\section{Aspects \& Issues of the Information Science and Technology (IST)}

Information Science or Information Science and Technology in respect of a subject/ branch mainly concerned with the following:

\section{Broadness}

Information Science is a broad domain incorporating information, technologies (mainly computing and information technologies), management (to manage the tools, systems and support), in addition to this Information Science and Technology irrespective of latest nomenclature normally concerned with the society, community and development perspective. Therefore a proper and sustainable Information Science and Technology is supported with broadness.

\section{Techno-Manual Management}

Information Science and Technology is a broad domain and that may not be with this nomenclature. Some of the nomenclatures as already depicted viz. Information Science/ Informatics, CIS, Information Systems, Information Systems and Technology, Information Systems and Management - and so on. And importantly in all these subjects (unlikely IT, Computer Science, Computer Engineering) manual information management concepts, aspects, tools and technologies should be there as per the nomenclature or basic role of Information Sciences.

\section{Interdisciplinary Facets}

The role of Information Sciences is to interact with other fields and domains for better and healthy information systems and infrastructure building. Further, Information Science and Technology is also dedicated to technological solutions to wider areas viz. biology, earth sciences, business and commerce, education and teaching etc. Hence this way, Information Science and Technology or similar nomenclature should deal with different interdisciplinary facets and roles. Therefore, there is a need to ensure properly to enhance society and other fields. 
IRA-International Journal of Management \& Social Sciences

Misconception Management

There are many misconceptions regarding Information Science and Technology and allied domains; and among these important are Information Science is the alternative name of Information Technology or ICT or Computer Science. However, Information Science consists of the information, management and societal (application oriented) aspects. Therefore, it is the need of the hour by the academicians, organizations, government bodies and universities regarding the awareness of Information Science/ IST/ allied nomenclature.

\section{Growing Nomenclature}

Since Information Science is a broad field it may not be with the same exact Information Science or Information Science and Technology nomenclatures. It may be with the nomenclature viz. Computer and Information Science, Information Science and Computing, Informatics, Information and Data Science, Information Systems and Management and so on. Further, many new domains specific nomenclature have also been emerging (apart from the traditional) viz. Environmental Informatics, Security Informatics, Educational Informatics, Nursing Informatics, Urban Informatics, etc.

\section{Technologies \& Emerging Technologies: The Different Context}

The field of Information Science (or allied nomenclature) with the motto of information delivery to the societies and organizations deals with various basic IT components viz. Web Technology, Networking Technology, Software Technology, Database Technology, Multimedia Technology, etc. But here Information Science is not focused on the design, development, and internal functionalities of such technologies. Here in Information Science, such technologies are only concentrated with the applications and interaction in the betterment of the societies, institutions, organizations, and individuals. Regarding the latest technologies such as Cloud Computing \&Virtualization, Big Data and Analytics, Internet of Things (IoT) and Allied Technologies also in respect of Information Science (or allied nomenclature) only deals with the utilization and interactions to different sectors. Therefore, Information Science (or allied nomenclature) should have all such things in order to make a societal and applied domain.

\section{Aspects \& Issues of the Emerging Technologies with reference to the Cloud, Big Data \& Allied Technologies}

The technologies in respect of Information Science or Information Science and Technology may be noted with following aspects-

\section{Cloud Computing \& Virtualization}

Cloud Computing is the advanced technology and dedicated to virtualization of the different IT infrastructure that has already been acknowledged and illustrated in this work but as far as the Information Science (or allied nomenclature) context such technologies need to adopt and offered (or teach) in the way of societal and application context instead of designing and development.

\section{Big Data and Analytics}

As far as Information Science (or allied nomenclature) is concerned the technologies such as Big Data, Data Science and Analytics should be concentrated on different applications and areas. Here this technology can be offered with the specializations in urbanization, rural development, business development; and so on.

\section{Internet of Things (IoT)}

The technologies of the Internet of Things also emerging rapidly in Computing, Computer Science and Information Technology but in respect to Information Science (or allied nomenclature), the IoT should be offered in accordance with the societal and different sector applications. 
IRA-International Journal of Management \& Social Sciences

Allied Technologies

Similar to the technologies mentioned here in this work viz. Cloud Computing \& Virtualization, Big Data and Analytics, Internet of Things (IoT) in respect of Information Science (or allied nomenclature) other technologies like Human-Computer Interaction, Usability Engineering, Cyber Technologies \& Security, etc. should be offered with the focus on applications rather mathematical designing and development [13], [14], [19].

\section{Aspects \& Issues of the Educational Aspects on IST, the Cloud, Big Data \& Allied Technologies}

Information Science (IST) or any other nomenclature with the similar aim and agenda) these days not only offered with the skills or modern and emerging technologies but also with the concentration/ specialization of such technologies but there are certain issues to be noted and undertaken viz.-

\section{Country \& Territory}

It is worthy to note that Information Science or Information Science and Technology is varying country to country, and similarly the latest technologies if offered in IST or Information Science context as a degree or specialization must be with the basic motto of information and technologies for all the fields and domains. Here it is noted with this research work/study that different countries and territories are offering the emerging technological specialization with different thoughts and contexts. Therefore, a proper strategy is needed to follow up with the information and societal interaction agenda [10], [16], [17].

Manpower-Status and Demand

The manpower and Human Resource related aspects and issues are also important/ valuable in certain contexts regarding Information Science or Information Science and Technology since it holds different attributes and offering (viz. manual, computational, technology-specific, domain-specific, etc.). Hence proper steps are essential based on needs in different sectors and organizations.

\section{In Multiple Streams}

Information Science or IST based emerging technologies are offered in multiple streams, i.e. Computer Science, Computer Applications, IT etc. but the focus of such fields should be always different. And many follow the approaches of iSchools Organizations or other popular Information Science or Information Science and Technology Schools [9], [19], [24].

\section{In Different Platforms}

In Information Science or IST same specializations viz. Cloud Computing or any domain-specific specialization viz. Health Informatics may be offered with different platforms (following the iSchools/ IST principles) like Informatics, CIS, Information Systems; but there should be basic differences among such platforms.

\section{Future Demand}

Information Science or Information Science and Technology in general with other allied nomenclature, domainspecific nomenclature, skill-specific nomenclature need to offer based on future demand and need of the sector, industries. As Information is most vital and required, therefore, proper steps and policies also need to follow up.

\section{Supports}

Supports from different levels of stakeholders are better to reach the ultimate aim and objective of the Information Science or Information Science and Technology. And in this context support may be in the form of technologies, finance, and funding, proper policies of the Government and Bodies, etc. 
IRA-International Journal of Management \& Social Sciences

\section{Conclusion}

Therefore, for the development of different perspectives, and sectors, Information Science of all sorts is the need of the hour. Since Information Science is worthy deals for all, therefore multiple efforts and initiatives need to take care of as well to make an intelligent society with sustainability. Technologies are changing rapidly and there are various requirements in proper utilization of the information science benefits in a different context and such healthy utilization will lead to the proper and healthy development in society and organization properly.

\section{References}

[1]. Adamuthe, A. C., Salunkhe, V. D., Patil, S. H., \& Thampi, G. T. (2015). Cloud Computing-A market Perspective and Research Directions. International Journal of Information Technology and Computer Science (IJITCS), 7(10), 42-53.

[2]. Al-Mamary, Y. H., Shamsuddin, A., \& Abdul Hamid, N. A. (2014). The meaning of management information systems and its role in telecommunication companies in Yemen. American Journal of Software Engineering, 2(2), 22-25.

[3]. Arch-int, S., \& Batanov, D. N. (2003). Development of industrial information systems on the Web using business components. Computers in Industry, 50(2), 231-250.

[4]. Brock, F. J., \& Dhillon, G. S. (2001). Managerial information, the basics. Journal of International Information Management, 10(2), 5.

[5]. Cram, W. A., Brohman, K., \& Gallupe, R. B. (2016). Information systems control: A review and framework for emerging information systems processes. Journal of the Association for Information Systems, 17(4), 2.

[6]. Bansal, Alka et.al (2005). Securing the future of Information: Digitization and Preservation of Documents in eFormat.DESIDOC Bulletin of Information Technology, 25(1), 19-26.

[7]. Buckland, Michael K and Liu (1995). History of Information Science. Annual Review of Information Science and Technology, 30(1), 385-416.

[8]. Wang, C., Wang, Q., Ren, K. and Lou, W. (2010). Privacy-Preserving Public Auditing for Data Storage Security in Cloud Computing, Proceedings of IEEE-INFOCOM, March, 1-9.

[9]. Mangla PB (2003). Information Society, Information Systems And National Development: A Conceptual Approach. In Annals of Library and Information Studies,50(2), 91-98.

[10]. N Chandrakant, et.al. (2011). Maximizing Lifetime of Wireless Sensor Network by using energy efficient middleware service. International Journal of Innovative Technology and Creative Engineering, 1(1), 20-24.

[11]. N. Chandrakant (2013). Green Computing and Mobile Cloud Computing inspired Middleware for Next Generation. International Journal of Advanced Research in Computer Science and Electronics Engineering, 2(7), $542-545$.

[12]. Nithya Sankar and Dr. S.S. Rau, (2011). Managing Emotions to Managing Human Capital.International Journal of Management (IJM), 2(2), 176 - 181 .

[13]. Pau1, Prantosh Kumar, Dipak Chaterjee (2012). Cloud Computing and Green Computing: Challenges and Issues in Indian perspective. Asian Journal of Computer Science and Technology, 1(2), 50-54.

[14]. Pau1, Prantosh Kumar, et.al (2012). Artificial Intelligence and Expert Systems: its emerging interaction and importance in Information Science- An overview. Asian Journal of Electrical Sciences, 1(2), 06-10.

[15]. Paul, Prantosh Kumar (2013a). Information Science and Technology [IST] and its comparision with Information Technology and Social Computing. Abhinav National Journal of Science and Technology, 2(3), 17-25.

[16]. Paul, Prantosh Kumar (2013e). Social Computing and Social Informatics: The stakeholders of Knowledge Society emphasizing similarities and dissimilarities at a glance. In Abhinav National Journal of Science and Technology, 2(4), 25-32.

[17]. Paul, Prantosh Kumar, Kumar, K., Chatterjee, D. (2013). Information Visualization: The way of Visual representation of data and information - The healthy information practice. IEEE sponsored proceedings of National Conference on Information and Software Engineering, 127. 
[18]. Paul, Prantosh Kumar, K. Kumar, D. Chatterjee, Minakshi Ghosh, K.S. Shivraj and Jhuma Ganguly (2014). Information Science: The Multidisciplinary, Interdisciplinary field for Information cumTechnological Solution for People and Wider Community. International Journal of Information Science and Computing, 1(1), 25-29.

[19]. Bianchini, R. and Rajamony, R. (2004). Power and energy management for server systems. in IEEE Computer, 37(2), 68-74.

[20]. Sharmila, R. and Subramani, A. (2013). Impact of Business Intelligence Tools in Executive Information Systems.International Journal of Computer Engineering and Technology (IJCET), 4(1), 1-7.

[21]. Raghvan, K.S (2007). Education For The Information Management Profession: Challenge And Opportunities.DESIDOC Bulletin of Information and Technology, 27(2), 21-26.

[22]. Vickery, Brian C. (1994). Fifty Years of Information Progress: A Journal of Documentation Review. London, England: in ASLIB; Page-243.

[23]. Boyd, W. Rayward, (1997). The Origin of Information Science and the International Institute of Bibliography/ International Federation for Information and Documentation.Journal of the American Society for Information Science, 48(4), 289-300.

[24]. Kintsch, W. (2003). On the notion of theme and topic in psychological process models of text comprehension. W.v. Peer, Parsing for the theme. A computer-based approach. Amsterdam, Philadelphia: John Benjamins Publishing, 158-170. 